\title{
Analisis Faktor-Faktor Penentu Pembiayaan Perbankan Syariah pada Sektor Pengangkutan dan Komunikasi di Indonesia
}

\section{The Analysis of Determinant Factors in Islamic Banking on Financing of Transportation and Communication Sectors in Indonesia}

\author{
Yozar Putra Jaya ${ }^{1}$, Wiwiek Rindayati ${ }^{2}$, Khalifah Muhammad Ali ${ }^{3}$ \\ ${ }^{1}$ Alumnus Program Studi Ilmu Ekonomi Syariah, Institut Pertanian Bogor, Email yozarpj@yahoo.com \\ ${ }^{2}$ Dosen Program Studi Ekonomi Studi Pembangunan, Institut Pertanian Bogor, Email wiwiekrinda@ yahoo.com \\ ${ }^{3}$ Dosen Program Studi Ilmu Ekonomi Syariah, Institut Pertanian Bogor, Email khalifahma@ gmail.com
}

\begin{abstract}
The Transportation and communications sector acts as liaison between economy of islands in Indonesia, it's required helping through the distribution of Islamic Banking funding. This study aims to analyze the influence, shock response, and variety contribute of some factors as banking performance, macroeconomic condition, rate of return, and monetary instruments towards trasportation, warehousing, and communication (TWC) financing in Islamic banking. This study uses Vector Error Correction Model. The results of this study, first, in the short term DPK variabel is affected significantly towards ratio of financing TWC sectors. In the long term NPF, INF, ERP, PUAS, SBK variabels are giving significantly negative effect towards ratio of financing TWC sectors, whereas IPI and BSBIS variabels are giving significantly positif effect. Second, the ratio of TWCsectors responds negatively to the shock of NPF, PUAS, ERP, and INF variabels, whereas the shock of DPK, BSBIS, and SBK variabels is responded positively by the ratio of TWC sectors. Third, BSBIS variable gives the largest contribution to the diversity of financial ratios TWC, then proceed ERP, NPF, and IPI.
\end{abstract}

Keywords: Financing, Islamic Banking, Transportation and Communication Sectors, VECM

\begin{abstract}
Abstrak. Sektor pengangkutan dan komunikasi berperan sebagai penghubung perekonomian antar pulau di Indonesia, diperlukan peran perbankan syariah dalam membantu akses permodalan untuk mengembangkan sektor tersebut. Tujuan dari penelitian ini adalah menganalisis pengaruh, respon guncangan, dan kontribusi keragaman faktor-faktor kategori kinerja perbankan, kondisi makroekonomi, rate of return, dan instrumen moneter terhadap rasio pembiayaan sektor pengangkutan, pergudangan dan komunikasi (PPK) pada perbankan syariah. Penelitian ini menggunakan metode Vector Error Corection Model (VECM). Hasil penelitian menunjukkan bahwa pada jangka pendek variabel Dana Pihak Ketiga (DPK) berpengaruh negatif secara signifikan terhadap rasio pembiayaan PPK dan pada jangka panjang variable Non Performing Financing (NPF), tingkat inflasi (INF), equivalent rate pembiayaan (ERP), Pasar Uang Antar Bank berdasarkan prinsip Syariah (PUAS), suku bunga kredit (SBK) secara signifikan berpengaruh negatif terhadap rasio pembiayaan PPK sedangkan variabel Industrial production Index (IPI) dan bonus Sertifikat Bank Indonesia Syariah (BSBIS) secara signifikan berpengaruh positif.
\end{abstract}

Kata Kunci: Pembiayaan, Perbankan Syariah, Sektor Pengangkutan dan Komunikasi, VECM

\section{Pendahuluan}

Indonesia merupakan negara kepulauan terbesar di dunia yang memiliki aktivitas perekonomian yang sangat padat (Kementerian Kelautan dan Perikanan 2012). Keadaan ini mengakibatkan dibutuhkannya suatu sarana dan prasarana yang mampu menunjang keberlangsungan dari aktivitas perekonomian tersebut. Sektor pengangkutan dan komunikasi merupakan salah satu sektor penting yang mampu menyediakan sarana dan prasarana yang dapat menunjang berbagai aktivitas dalam perekonomian di Indonesia.

Subsektor pengangkutan memiliki peran sebagai penyedia jasa pelayanan bagi mobilitas penduduk dan juga perekonomian. Subsektor pengangkutan meliputi kegiatan pengangkutan umum untuk barang dan penumpang melalui darat, laut, sungai, danau, dan udara. Termasuk di sini jasa penumpang angkut yang mencakup pemberian jasa atau penyediaan fasilitas yang sifatnya menunjang dan memperlancar kegiatan pengangkutan, seperti jasa-jasa terminal, pelabuhan, bongkar muat, jalan tol, pergudangan dan jasa penunjang lainnya.

Jurnal Al-Muzara'ah, Vol. 3, No. 1

(ISSN p: 2337-6333; e: 2355-4363) 
Subsektor komunikasi berperan sebagai penyedia jasa telekomunikasi yang mampu menghubungkan pulau-pulau di seluruh Indonesia. Subsektor komunikasi meliputi berbagai kegiatan yang berhubungan dengan dunia informasi seperti penyiaran radio dan TV, penerbitan buku, jurnal, famplet dan surat kabar. Selain itu sektor komunikasi juga menyediakan jasa telekomunikasi seperti pemograman, konsultasi komputer baik perangkat keras maupun lunak, jasa penyediaan web hosting, dan penyediaan jaringan transmisi suara beserta pemancarnya.

Keberadaan sektor pengangkutan dan komunikasi terasa begitu amat vital bagi perekonomian Indonesia, dengan peningkatan kerja sektor tersebut maka akan meningkatkan produktivitas, kesempatan kerja dan laju perekonomian Indonesia. Menurut data Badan Pusat Statistik (BPS) 2014, distribusi Produk Domestik Bruto (PDB) Indonesia didominasi oleh sektor industri pengolahan dengan kontribusi sebesar $23.71 \%$, diikuti oleh sektor pertanian, peternakan, kehutanan, dan perikanan yang berkontribusi sebesar $14.33 \%$ (BPS 2014). Kontribusi sektor pengangkutan dan komunikasi terhadap PDB pada tahun 2014 menempati peringkat ke delapan dari sembilan sektor perekonomian yang ada di Indonesia dengan kontribusi sebesar 7.39\%.

Kontribusi sektor pengangkutan dan komunikasi pada tahun 2014 memang masih relatif kecil, namun dalam enam tahun terakhir laju pertumbuhan kontribusi sektor pengangkutan dan komunikasi terhadap PDB terus meningkat setiap tahunnya. Tahun 2008 dan 2009 sektor pengangkutan dan komunikasi berkontribusi terhadap PDB sebesar 6.3\%, kemudian meningkat menjadi $6.5 \%$ pada tahun 2011. Tahun 2014 kontribusi sektor ini meningkat menjadi 7.39\%.

Berbeda dengan kontribusi yang diberikan, dalam hal pertumbuhan sektor pengangkutan dan komunikasi dalam enam tahun terakhir mampu menjadi sektor yang mengalami pertumbuhan tertinggi secara berturut-turut dengan rata-rata pertumbuhan berkisar $12.23 \%$. Sektor pengangkutan dan komunikasi mampu mengungguli pertumbuhan sektor-sektor lain yang mampu memberikan kotribusi besar bagi komposisi PDB Indonesia. Salah satunya sektor industri pengolahan yang dalam hal pertumbuhannya hanya mampu mencapai $4.63 \%$ secara rata-rata dalam enam tahun terakhir.

Di dalam nota Rancangan Anggaran Pendapatan dan Belanja Negara (RAPBN) 2015, sektor pengangkutan dan komunikasi di tahun 2015 diperkirakan memiliki pertumbuhan tertinggi di antara sektor yang lain, yaitu sebesar 9.5\%. Selain tingginya permintaan masyarakat akan kebutuhan telekomunikasi, pertumbuhan sektor tersebut didukung oleh kebijakan di sektor transportasi tahun 2015 yaitu penguatan konektivitas nasional. Program yang akan dilaksanakan diantaranya adalah pembangunan jalan baru, rel kereta api berjalur ganda, pelabuhan di wilayah timur, serta penambahan sarana transportasi yang meliputi bus, kapal perintis, kereta ekonomi, dan kereta rel listrik. Sasaran lain dari program tersebut juga ditujukan pada terbangunnya sistem transportasi angkutan massal berbasis bus dan rel guna mengurangi kemacetan lalu lintas dan meningkatkan pergerakan manusia di perkotaan. Tidak hanya itu, tersedianya layanan komunikasi dan informatika di wilayah perdesaan, perbatasan negara, dan pulau terluar juga menjadi perhatian untuk meningkatkan akses pelayanan telekomunikasi universal dan internet

Berdasarkan Rancangan Pembangunan Jangka Menengah Nasional (RPJMN) tahun 2015-2019, program pembangunan yang dicanangkan pada tahun 2015 hingga 2019 tersebut ditaksir akan memerlukan dana sebesar 2058.8 triliun rupiah. Besarnya dana yang diperlukan tidak mungkin hanya dibiayai oleh APBN saja namun juga diperlukan sokongan dana dari berbagai kalangan. Salah satu pihak yang dinilai mampu untuk mendanai program pembangunan pada sektor pengangkutan dan komunikasi yaitu industri perbankan. Dunia perbankan diharapkan dapat membantu akses permodalan dalam mendukung penyelenggaraan kegiatan yang berkaitan dengan pengembangan sektor pengangkutan dan komunikasi melalui penyaluran kredit atau pembiayaan.

Perbankan merupakan lembaga keuangan yang memiliki fungsi intermediasi dalam menghimpun dana dari pihak yang kelebihan dana dan menyalurkan kembali dana tersebut pada pihak yang membutuhkan. Sektor perbankan di Indonesia sudah mengenal sistem perbankan baru yaitu sistem perbankan syariah yang menerapkan berbagai macam akad yang mengatur setiap kegiatan perbankan 
dengan prinsip islami. Perbankan syariah diyakini dapat menguntungkan berbagai pihak dan memiliki beberapa keunggulan daripada perbankan konvensional.

Salah satu keunggulan yang dimiliki yaitu diterapkannya sistem bagi hasil dan menghapus beban bunga yang berkelanjutan. Keunggulan tersebut diyakini dapat menjadikan perbankan syariah menjadi salah satu alternatif terbaik dalam memberikan pembiayaan pada sektor pengangkutan dan komunikasi. Berdasarkan Statistik Perbankan Syariah Bank Indonesia (SPS-BI), total aset perbankan syariah dari tahun ke tahunnya terus mengalami peningkatan. Besarnya aset yang dimiliki tidak lepas dari jumlah Dana Pihak Ketiga (DPK) yang dapat dihimpun oleh perbankan syariah. Dalam ajaran Islam keberadaan DPK ini tidak boleh terus-menerus disimpan, tetapi harus ada pemanfaatan yang dilakukan oleh perbankan syariah yaitu melalui pembiayaan yang diberikan kepada sektor riil.

Berdasarkan SPS-BI (2014) pembiayaan yang diberikan perbankan syariah pada sektor riil terbilang besar, hal ini dapat dibuktikan dengan tingginya pembiayaan yang disalurkan pada tahun 2014 yaitu sebesar 199330 milliar rupiah. Besarnya jumlah pembiayaan yang disalurkan terhadap sektor riil, diharapkan dapat membantu permodalan terhadap sektor pengangkutan dan komunikasi sehingga dapat mendorong laju pertumbuhan ekonomi Indonesia.

Menurut SPS-BI (2014), persentase rasio pembiayaan sektor pengangkutan, pergudangan dan komunikasi (PPK) terhadap total pembiayaan perbankan syariah mengalami fluktuasi dari tahun 2008 ke tahun 2014 dan cenderung mengalami penurunan (Gambar 1). Hal ini menunjukkan bahwa total pembiayaan yang meningkat setiap tahunnya belum tentu akan diikuti dengan pertumbuhan pembiayaan pada sektor PPK. Secara umum faktor-faktor yang mempengaruhi besarnya pembiayaan perbankan adalah posisi permodalan bank, risiko kebijakan fiskal dan moneter yang berlaku, kemampuan dari bank sendiri serta kebutuhan kredit dalam suatu wilayah (Reed 1989). Menurut Pohan (2008), perilaku penawaran kredit perbankan juga dipengaruhi oleh suku bunga, persepsi bank terhadap prospek usaha debitur dan kondisi internal perbankan itu sendiri seperti tercermin pada permodalan atau Capital Adequacy Ratio (CAR), jumlah kredit macet atau Non Performing Loan (NPL), dan Loan to Deposit Ratio (LDR).

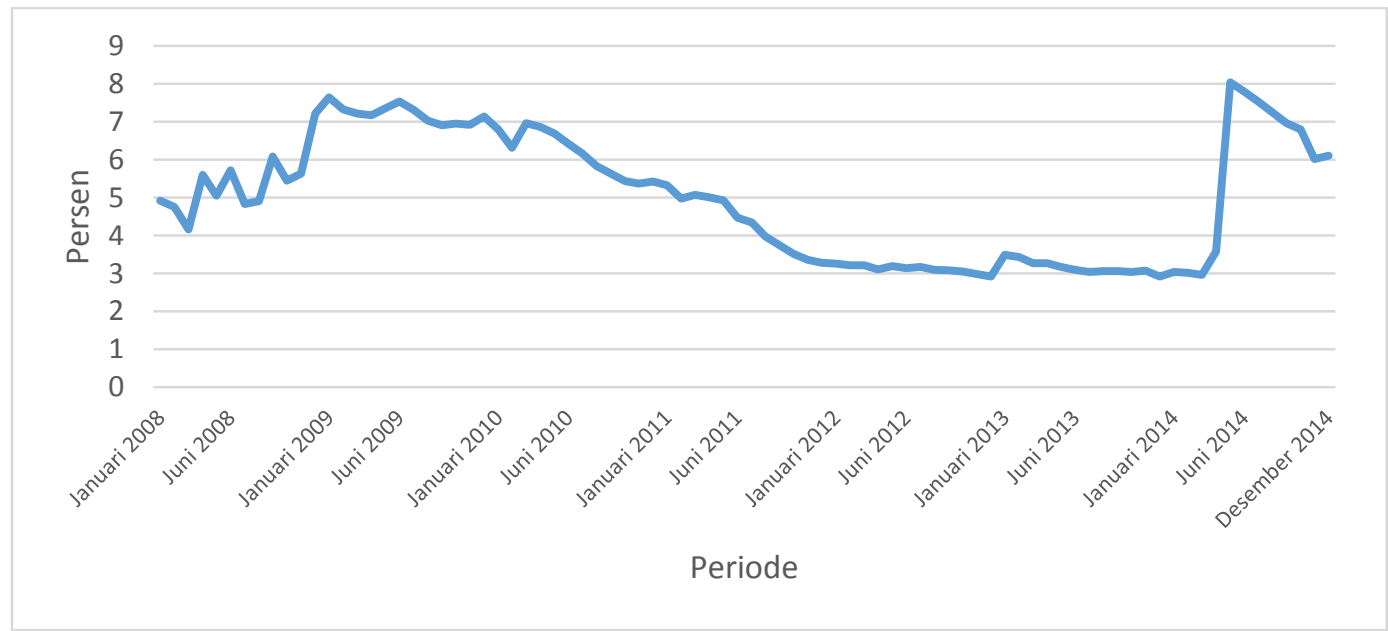

Sumber: Statistik Perbankan Syariah Bank Indonesia Tahun 2014 (diolah)

\section{Gambar 1 Perkembangan Rasio Pembiayaan Sektor PPK terhadap Total Pembiayaan Perbankan Syariah}

Penelitian ini dilakukan untuk menganalisis faktor-faktor apa saja yang mempengaruhi menurunnya rasio pembiayaan sektor PPK terhadap total pembiayaan pada perbankan syariah. Untuk mengetahui hal tersebut maka penelitian ini akan mengkaitkan sejauh mana kategori kinerja perbankan syariah, kategori kondisi makroekonomi, kategori instrumen moneter, dan kategori rate of return pembiayaan dalam mempengaruhi rasio pembiayaan sektor PPK pada perbankan syariah. Penelitian ini bertujuan untuk mengetahui faktor-faktor apa saja yang menyebabkan penurunan rasio pembiayaan sektor PPK 
terhadap total pembiayaan perbankan syariah, sehingga dapat dirumuskan rekomendasi untuk mengoptimalkan pembiayaan sektor PPK pada perbankan syariah di Indonesia dengan berbasiskan hasil penelitian.

Ruang lingkup penelitian ini dibatasi hanya pada pembiayaan sektor pengangkutan dan komunikasi, namun perbankan syariah menambahkan subsektor pergudangan dalam bagian dari penamaan pada pembiayaan yang disalurkan, sedangkan subsektor pergudangan merupakan bagian dari sektor pengangkutan. Selanjutnya penelitian ini mengenal istilah sektor pengangkutan dan komunikasi menjadi sektor pengangkutan, pergudangan dan komunikasi (PPK). Selain itu, ruang lingkup perbankan syariah yang diteliti dibatasi hanya pada Bank Umum Syariah (BUS) dan Unit Usaha Syariah (UUS), tanpa menyertakan data dari Bank Pembiayaan Rakyat Syariah (BPRS). Dikarenakan terbatasnya ketersediaan data publikasi terhadap perbankan syariah dalam pembiayaan sektor PPK maka penelitian ini hanya menggunakan data bulanan yang dimulai dari Januari 2008 sampai dengan Desember 2014.

Faktor-faktor yang digunakan dalam penelitian ini dibatasi hanya pada beberapa variabel. Variabel yang digunakan untuk menggambarkan kinerja perbankan diantaranya yaitu rasio pembiayaan sektor PPK (Rasio_PPPK), Non Performing Financing (NPF) sektor PPK, dan Dana Pihak Ketiga (DPK). Lalu Variabel yang menggambarkan kondisi makroekonomi Indonesia diantaranya tingkat inflasi (INF) dan Industrial Production Index (IPI). Selanjutnya proksi dari rate of return yaitu variabel equivalent rate pembiayaan (ERP) sektor PPK dan suku bunga kredit bank konvensional (SBK) sektor PPK. Terakhir adalah variabel yang menggambarkan instrumen moneter yaitu bonus Sertifikat Bank Indonesia Syariah (BSBIS) dan penempatan dana pada Pasar Uang Antar Bank dengan prinsip Syariah (PUAS).

\section{Metode Penelitian}

\subsection{Jenis dan Sumber Data}

Data yang digunakan yaitu data sekunder dengan frekuensi bulanan dari Januari 2008 sampai dengan Desember 2014 yang bersangkutan dengan pembiayaan yang diberikan Bank Umum Syariah (BUS) dan Unit Usaha Syariah (UUS). Data bersumber dari publikasi Bank Indonesia antara lain Statistik Perbankan Syariah Bank Indonesia (SPS-BI), Statistik Perbankan Indonesia (SPI), dan Statistik Ekonomi dan Keuangan Indonesia (SEKI) serta data dari Badan Pusat Statistika Indonesia (BPS). Penelitian ini juga menggunakan data pelengkap lainnya dari literatur-literatur yang berkaitan, jurnal, buku, dan dari media internet.

\subsection{Metode Analisis dan Pengolahan Data}

Penelitian ini menggunakan metode analisis yang bersifat deskriptif dan kuantitatif. Alat analisis yang digunakan dalam penelitian ini adalah metode Vector Autoregression (VAR). Metode ini diterapkan apabila data-data yang digunakan stasioner pada level dan tidak terkointegrasi. Kemudian dilanjutkan dengan metode Vector Error Correction Model (VECM) apabila data-data yang digunakan tidak stasioner pada level tetapi stasioner pada first difference dan terdapat kointegrasi. Pengolahan data pada penelitian ini dilakukan secara bertahap, artinya sebelum sampai pada analisis VAR dan VECM perlu dilakukan beberapa pengujian praestimasi yaitu, uji non-stationeritas data atau uji akar unit (unit root test), penentuan panjang lag optimum, dan uji stabilitas VAR. Selanjutnya, dilakukan uji kointegrasi, estimasi VECM, Impuls Response Function (IRF), dan Forecast Error Variance Decomposition (FEVD). Perangkat lunak yang digunakan untuk proses pengolahan adalah Microsoft Excel 2013 dan Eviews 6. 


\subsection{Model Penelitian}

Model Penelitian yang digunakan yaitu VECM, dengan spesifikasi model sebagai berikut:

Keterangan:

$$
\Delta y_{t}=\mu_{0 x}+\mu_{1 x} t+\prod_{x} y_{t-1}+\sum_{i=1}^{k-1} \Gamma_{k} \Delta y_{t-i}+\varepsilon_{t}
$$

$\mathrm{y}_{\mathrm{t}} \quad$ : vektor yang berisi variabel yang dianalisis dalam penelitian

$\mu_{\mathrm{ox}} \quad$ : vektor intercept

$\mu_{1 x} \quad$ : vektor koefisien regresi

$\mathrm{t} \quad$ : time trend

$\prod_{x} \quad: \alpha_{x} \beta$ ' dimana b' mengandung persamaan kointegrasi jangka panjang

$\mathrm{y}_{\mathrm{t}-1} \quad$ : variabel in-level

$\Gamma_{\dot{k}} \quad$ : matriks koefisien regresi

$\mathrm{k}-1$ : ordo VECM dari VAR

$\varepsilon_{t} \quad$ : error term

Model persamaan VECM dalam bentuk notasi matriks yang digunakan dalam penelitian ini adalah sebagai berikut:

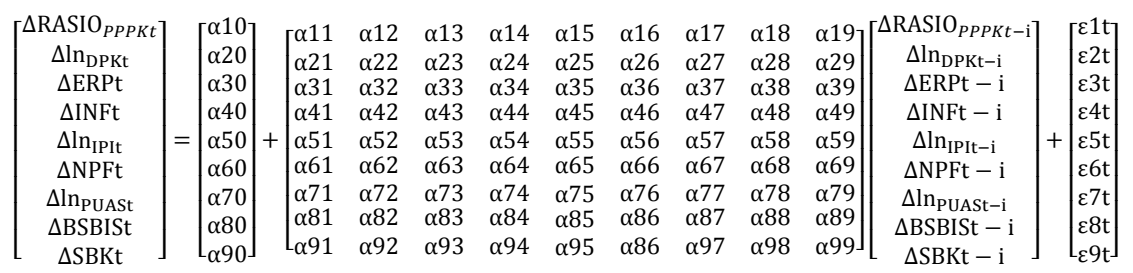

Keterangan :

Rasio PPPK : Rasio pembiayaan sektor PPK terhadap total pembiayaan perbankan syariah (persen) LnDPK : Total DPK perbankan syariah (Milliar Rp)

$\begin{array}{ll}\text { ERP } & \text { : Equivalent rate pembiayaan (persen) } \\ \text { INF } & : \text { Tingkat Inflasi (persen) } \\ \text { LnIPI } & \text { : Industrial Production Index (unit) } \\ \text { NPF } & : \text { Non Performing Financing (persen) } \\ \text { LnPUAS } & \text { : Penempatan dana pada PUAS (Milliar Rp) } \\ \text { BSBIS } & : \text { Bonus Sertifikat Berharga Indonesia Syariah (persen) } \\ \text { SBK } & : \text { Suku Bunga Kredit (persen) }\end{array}$

\section{Hasi dan Pembahasan}

\subsection{Hasil Uji Non-Stasioneritas Data}

Pengujian stasioneritas pada penelitian ini menggunakan uji Augmented Dickey Fuller (ADF). Pengujian dilakukan pada tahap level sampai dengan first difference dengan menggunakan asumi Schwarz Information Criterion pada automatic lag length selection dengan maximum lag sebesar 11.

Tabel 1 Hasil Uji Stasioneritas Data

\begin{tabular}{ccccccc}
\hline Variabel & & LEVEL & & \multicolumn{3}{c}{ FIRST DIFFERENCE } \\
& Nilai & Nilai & Keterangan & Nilai & Nilai & Keterangan \\
& Statistik & Kritis Mac & & Statistik & Kritis Mac & \\
& ADF & Kinnon 5\% & & ADF & Kinnon 5\% & \\
\hline Rasio & -1.63932 & -2.896779 & Tidak Stasioner & $\mathbf{- 8 . 9 8 8 1 0 5}$ & -2.897223 & Stasioner \\
PPPK & & & & & &
\end{tabular}




\begin{tabular}{ccccccc} 
DPK & $\mathbf{- 4 . 0 6 9 4 9}$ & -3.464865 & Stasioner & $\mathbf{- 1 0 . 0 6 2 4 5}$ & -3.465548 & \multicolumn{2}{c}{ Stasioner } \\
ERP & -1.70650 & -2.896779 & Tidak stasioner & $\mathbf{- 1 1 . 4 7 8 3 9}$ & -2.897223 & Stasioner \\
\hline Variabel & & LEVEL & & \multicolumn{3}{c}{ FIRST DIFFERENCE } \\
& Nilai & Nilai & Keterangan & Nilai & Nilai & Keterangan \\
& Statistik & Kritis Mac & & Statistik & Kritis Mac & \\
& ADF & Kinnon 5\% & & ADF & Kinnon 5\% & \\
& & & & & & \\
\hline INF & -2.35454 & -2.903566 & Tidak Stasioner & $\mathbf{- 4 . 5 0 8 0 5 2}$ & -2.897223 & Stasioner \\
IPI & $\mathbf{- 6 . 2 4 4 4 3}$ & -3.464865 & Stasioner & $\mathbf{- 8 . 2 1 2 7 1 1}$ & -3.466966 & Stasioner \\
NPF & -3.00042 & -3.464865 & Tidak stasioner & $\mathbf{- 9 . 4 6 2 5 7 1}$ & -3.465548 & Stasioner \\
PUAS & -1.13124 & -2.896779 & Tidak stasioner & $\mathbf{- 6 . 3 4 3 6 0 3}$ & -2.899115 & Stasioner \\
BSBIS & -2.06112 & -2.896779 & Tidak stasioner & $\mathbf{- 3 . 9 6 9 2 6 2}$ & -2.897678 & Stasioner \\
SBK & -1.06336 & -2.896779 & Tidak stasioner & $\mathbf{- 7 . 4 4 4 7 2 8}$ & -2.897223 & Stasioner \\
\hline
\end{tabular}

Data dikatakan stasioner adalah ketika nilai statistik ADF kurang dari nilai kritis MacKinnon. Hasil yang dicetak tebal pada Tabel 7 menunjukkan data yang stasioner baik pada level maupun first difference. Hasil pengujian menunjukkan variabel yang stasioner di level yaitu variabel DPK dan IPI. Sedangkan pada first difference semua variabel stasioner. Oleh karena itu, akan dilakukan pengujian kointegrasi, jika terdapat kointegrasi maka akan digunakan model Vector Error Correction Model (VECM), namun apabila tidak terdapat kointegrasi maka akan digunakan VAR first difference.

\subsection{Hasil Uji Stabilitas VAR}

Tabel 2 Hasil Uji Stabilitas VAR

\begin{tabular}{ll}
\hline Root & Modulus \\
\hline 0.982567 & 0.982567 \\
$0.887469-0.086074 \mathrm{i}$ & 0.891633 \\
$0.887469+0.086074 \mathrm{i}$ & 0.891633 \\
$0.863731-0.187807 \mathrm{i}$ & 0.883913 \\
$0.863731+0.187807 \mathrm{i}$ & 0.883913 \\
0.819017 & 0.819017 \\
$0.526653-0.110871 \mathrm{i}$ & 0.538197 \\
$0.526653+0.110871 \mathrm{i}$ & 0.538197 \\
\hline 0.173542 & 0.173542 \\
\hline
\end{tabular}

Uji stabilitas VAR dilakukan untuk mendapatkan nilai dan hasil yang valid pada Impulse Response Function dan Forecast Error Variance Decomposition. Model VAR dinyatakan stabil jika root-nya memiliki nilai modulus kurang dari satu. Berdasarkan uji stabilitas VAR yang dilakukan terlihat bahwa nilai modulus dari seluruh roots memiliki nilai modulus kurang dari satu, sehingga dapat disimpulkan bahwa model VAR yang digunakan dalam penelitian ini telah stabil pada lag optimalnya yaitu lag satu.

\subsection{Hasil Uji Lag Optimum}

Besarnya lag pada penelitian ini dipilih berdasarkan kriteria Schwarz Information Criterion (SC). Berdasarkan Tabel 8 nilai SC terkecil terdapat pada lag satu dengan nilai sebesar 0.875213. Dengan demikian, lag yang akan digunakan dalam model sebagai lag optimum adalah lag satu. Hal ini mengindikasikan bahwa kejadian saat ini dipengaruhi oleh kejadian satu periode sebelumnya.

Tabel 3 Hasil Uji Lag Optimum

\begin{tabular}{ccccccr}
\hline Lag & LogL & LR & FPE & AIC & SC & \multicolumn{1}{c}{ HQ } \\
\hline 0 & -485.6411 & NA & $3.07 \mathrm{e}-06$ & 12.84782 & 13.12177 & 12.95740 \\
1 & 161.7756 & 1126.673 & $1.27 \mathrm{e}-12$ & -1.864300 & $0.875213^{*}$ & -0.768519 \\
2 & 231.5671 & 105.1405 & $1.84 \mathrm{e}-12$ & -1.573172 & 3.631903 & 0.508812 \\
3 & 296.3961 & 82.50961 & $3.49 \mathrm{e}-12$ & -1.153145 & 6.517491 & 1.915042
\end{tabular}




\begin{tabular}{lllllll}
4 & 370.4561 & 76.94543 & $6.64 \mathrm{e}-12$ & -0.972885 & 9.163313 & 3.081505 \\
5 & 479.4949 & 87.79748 & $7.69 \mathrm{e}-12$ & -1.701165 & 10.90059 & 3.339427 \\
6 & 659.2515 & 102.7181 & $2.98 \mathrm{e}-12$ & -4.266273 & 10.80105 & 1.760523 \\
7 & 1061.029 & $135.6652 *$ & $1.80 \mathrm{e}-14^{*}$ & $-12.59816^{*}$ & 4.934724 & $-5.585160^{*}$ \\
\hline
\end{tabular}

\subsection{Hasil Uji Kointegrasi}

Pengujian kointegrasi dilakukan dengan menggunakan uji Johanssen's Trace Statistic untuk mengetahui berapa banyak persamaan dalam sistem yang memiliki kointegrasi. Hubungan kointegrasi dalam penelitian ini dapat dilihat dari nilai trace statistic. Terdapat hubungan kointegrasi apabila nilai trace statistic lebih besar dari nilai critical value 5\%.

Tabel 4 Hasil Uji Kointegrasi

\begin{tabular}{|c|c|c|c|c|}
\hline $\begin{array}{l}\text { Hypothesized } \\
\text { No. of CE(s) }\end{array}$ & Eigenvalue & $\begin{array}{c}\text { Trace } \\
\text { Statistic }\end{array}$ & $\begin{array}{c}0.05 \\
\text { Critical Value }\end{array}$ & Prob.** \\
\hline None* & 0.546426 & 226.0568 & 179.5098 & 0.0000 \\
\hline At most $1 *$ & 0.456492 & 161.2277 & 143.6691 & 0.0034 \\
\hline At most 2 & 0.380630 & 111.2314 & 111.7805 & 0.0541 \\
\hline At most 3 & 0.258877 & 71.94915 & 83.93712 & 0.2682 \\
\hline At most 4 & 0.184590 & 47.38283 & 60.06141 & 0.3654 \\
\hline At most 5 & 0.147320 & 30.64958 & 40.17493 & 0.3214 \\
\hline At most 6 & 0.103751 & 17.58117 & 24.27596 & 0.2755 \\
\hline At most 7 & 0.077613 & 8.599156 & 12.32090 & 0.1938 \\
\hline At most 8 & 0.023789 & 1.974311 & 4.129906 & 0.1885 \\
\hline
\end{tabular}

Keterangan: Tanda (*) menunjukkan adanya kointegrasi.

Berdasarkan hasil uji Johanssen's Trace Statisctic pada Tabel 10, model yang digunakan pada penelitian ini memiliki dua persamaan kointegrasi. Persamaan kointegrasi ini menunjukkan bahwa diantara variabel-variabel yang diuji memiliki hubungan kombinasi linier yang bersifat stasioner (kointegrasi), hingga model VECM dapat dilakukan dalam penelitian ini.

\subsection{Hasil Estimasi VECM}

Hasil estimasi VECM yang terdapat pada Tabel 11 menunjukkan kombinasi hubungan jangka pendek menuju jangka panjang pada variabel rasio pembiayaan sektor PPK (Rasio_PPPK), DPK, ERP, inflasi, IPI, NPF, PUAS, BSBIS, SBK. Pengujian variabel-variabel tersebut dilakukan dengan menggunakan taraf nyata sebesar 5\%. Pada Tabel 11, hasil estimasi VECM menunjukkan bahwa terdapat nilai koreksi kesalahan sebesar -0.080933 yang secara statistik signifikan pada taraf nyata pengujian sebesar 5\%. Koreksi kesalahan berarti ketidakseimbangan (disequilibrium) akan dikoreksi sebesar -0.080933 untuk kembali pada keseimbangan jangka panjang di bulan berikutnya.

Pada jangka pendek, variabel yang mempengaruhi rasio pembiayaan sektor PPK secara signifikan adalah variabel DPK, sedangkan variabel lainnya menunjukkan pengaruh yang tidak signifikan terhadap rasio pembiayaan sektor PPK. Pada jangka panjang, variabel yang secara signifikan berpengaruh positif terhadap rasio pembiayaan sektor PPK yaitu variabel IPI dan BSBIS, sedangkan variabel ERP, INF, NPF, PUAS dan SBK secara signifikan berpengaruh negatif terhadap rasio pembiayaan sektor PPK. Sementara variabel yang tidak berpengaruh secara signifikan pada jangka panjang hanya variabel DPK.

Tabel 11 Hasil Estimasi VECM

\begin{tabular}{ccc}
\hline & Jangka Pendek & \\
\hline Variabel & Koefisien & t-statistik \\
\hline CointEq1 & $\mathbf{- 0 . 0 8 0 9 3 3}$ & {$[\mathbf{- 3 . 3 8 7 2 4}]$} \\
D(Rasio_PPPK(-1)) & 0.019575 & {$[0.17065]$}
\end{tabular}




\begin{tabular}{|c|c|c|}
\hline D(DPK(-1)) & -3.144148 & [-2.85797] \\
\hline $\mathrm{D}(\operatorname{ERP}(-1))$ & -0.203188 & {$[-1.40305]$} \\
\hline $\mathrm{D}(\mathrm{INF}(-1))$ & 0.069772 & [ 0.70358$]$ \\
\hline $\mathrm{D}(\mathrm{IPI}(-1))$ & 0.820721 & {$[0.39342]$} \\
\hline $\mathrm{D}(\mathrm{NPF}(-1))$ & 0.329802 & [ 1.00283$]$ \\
\hline D(PUAS(-1)) & 0.130781 & [ 1.25880$]$ \\
\hline $\mathrm{D}(\mathrm{BSBIS}(-1))$ & -0.220640 & {$[-1.21338]$} \\
\hline \multicolumn{3}{|c|}{ Jangka Pendek } \\
\hline Variabel & Koefisien & t-statistik \\
\hline $\mathrm{D}(\operatorname{SBK}(-1))$ & 0.337012 & [ 1.04095$]$ \\
\hline \multicolumn{3}{|c|}{ Jangka Panjang } \\
\hline DPK & -0.899748 & {$[-0.46681]$} \\
\hline NPF & -4.158204 & {$[-3.27415]$} \\
\hline INF & -0.494225 & {$[-2.31508]$} \\
\hline IPI & 11.45581 & [ 2.41737] \\
\hline BSBIS & 2.669798 & [ 4.17441] \\
\hline PUAS & -1.142584 & {$[-2.20289]$} \\
\hline ERP & 1.496164 & [ 5.99777] \\
\hline SBK & -2.089452 & {$[-2.90320]$} \\
\hline
\end{tabular}

Keterangan: Bercetak tebal menunjukkan variabel signifikan pada taraf nyata $5 \%$.

\subsubsection{Pengaruh DPK terhadap Rasio Pembiayaan PPK}

Variabel DPK berpengaruh negatif secara signifikan terhadap rasio pembiayaan PPK pada jangka pendek. Hal ini terjadi karena keputusan internal industri perbankan syariah yang mengalokasikan kenaikan jumlah DPK kepada sektor lain seperti sektor jasa dunia usaha yang dinilai lebih menguntungkan. Oleh karena itu kenaikan jumlah DPK tidak diikuti oleh peningkatan penyaluran dana pada sektor PPK, sedangkan pada jangka panjang, variabel DPK tidak berpengaruh secara signifikan.

\subsubsection{Pengaruh NPF terhadap Rasio Pembiayaan PPK}

Variabel Non Performing Financing (NPF) berpengaruh negatif secara signifikan terhadap rasio pembiayaan PPK pada jangka panjang dengan nilai koefisien sebesar -4.158204. Hal ini berarti ketika terjadi kenaikan NPF sebesar $1 \%$ maka akan menyebabkan penurunan rasio pembiayaan PPK sebesar 4.15\%. Hasil penelitian ini sesuai dengan hipotesis awal yang menyatakan bahwa apabila terjadi peningkatan NPF maka berpengaruh negatif terhadap pembiayaan termasuk rasio pembiayaan PPK.

Hubungan negatif antara rasio pembiayaan sektor PPK dan NPF terjadi karena semakin tinggi pembiayaan bermasalah pada sektor PPK maka akan menyebabkan dana perbankan syariah menjadi tidak dapat berputar dari satu nasabah ke nasabah lainnya. Hal ini menyebabkan turunnya minat perbankan syariah untuk menyalurkan pembiayaan pada sektor PPK dan mengalihkan pembiayaan pada sektor lain dengan tingkat NPF yang lebih rendah.

\subsubsection{Pengaruh Inflasi terhadap Rasio Pembiayaan PPK}

Variabel inflasi (INF) berpengaruh negatif secara singnifikan terhadap rasio pembiayaan sektor PPK pada jangka panjang dengan nilai koefisien sebesar -0.494225. Besaran koefisien pada variabel inflasi menunjukkan bahwa ketika adanya peningkatan inflasi sebesar $1 \%$ maka akan menyebabkan penurunan rasio pembiayaan sektor PPK sebesar $0.49 \%$. Hal ini sesuai dengan hipotesis awal yang menyatakan variabel inflasi memiliki hubungan negatif terhadap rasio pembiayaan sektor PPK. Hubungan negatif antara inflasi dan rasio pembiayaan sektor PPK dikarenakan apabila tingkat inflasi yang meningkat maka keadaan tersebut akan direspon oleh otoritas moneter yaitu BI dengan menerapkan kebijakan uang ketat (tight money policy). Hal ini berarti BI akan membatasi jumlah uang yang beredar antara lain dengan cara membatasi pemberian kredit dan pembiayaan. 


\subsubsection{Pengaruh IPI terhadap Rasio Pembiayaan PPK}

Variabel Industrial Production Index (IPI) berpengaruh positif secara signifikan terhadap rasio pembiayaan sektor PPK pada jangka panjang dengan nilai koefisien sebesar 11.45581. Besaran koefisien pada variabel IPI menunjukkan bahwa ketika adanya peningkatan variabel IPI sebesar $1 \%$ maka akan diikuti dengan peningkatan pada rasio pembiayaan sektor PPK akan sebesar $11.45 \%$. Hal ini sesuai dengan hipotesis awal yang menyatakan variabel IPI memiliki hubungan positif terhadap jumlah pembiayaan yang disalurkan pada sektor PPK. Keadaan ini dikarenakan ketika perekonomian dalam kondisi yang baik maka akan mendukung penyelenggaraan kegiatan perbankan, termasuk kegiatan penyaluran pembiayaan untuk sektor PPK, sehingga ketika IPI meningkat maka penyaluran dana untuk pembiayaan akan meningkat, termasuk untuk pembiayaan sektor PPK.

\subsubsection{Pengaruh BSBIS terhadap Rasio Pembiayaan PPK}

Variabel bonus SBIS berpengaruh positif secara signifikan terhadap rasio pembiayaan sektor PPK dengan nilai sebesar 2.669798. Hal ini menunjukkan bahwa ketika terjadi kenaikan sebesar $1 \%$ pada bonus SBIS maka akan diikuti dengan meningkatnya rasio pembiayaan sektor PPK sebesar $2.66 \%$. Hal tersebut terjadi karena ketika terjadi peningkatan pada bonus SBIS maka keuntungan yang diterima oleh perbankan syariah akan meningkat. Dewan Syariah Nasional Majelis Ulama Indonesia (DSN-MUI) menjelaskan bahwa SBIS merupakan surat berharga dalam mata uang rupiah yang diterbitkan oleh Bank Indonesia berjangka waktu pendek yang berlandaskan prinsip syariah. Bank syariah diperbolehkan menempatkan dana pada SBIS selama kelebihan dana yang dimiliki bank syariah telah tersalurkan pada sektor riil. Hasil yang menunjukkan hubungan positif antara bonus SBIS rasio pembiayaan menunjukkan bahwa kelebihan dana yang dimiliki oleh perbankan syariah difokuskan untuk meningkatkan pembiayaan pada sektor riil. Akibatnya pembiayaan perbankan syariah terhadap sektor riil akan meningkat dan diikuti dengan meningkatnya rasio pembiayaan PPK.

\subsubsection{Pengaruh PUAS terhadap Rasio Pembiayaan PPK}

Variabel PUAS pada jangka panjang berpengaruh negatif dan signifikan pada rasio pembiayaan sektor PPK dengan nilai sebesar -1.142584. Hal ini menunjukkan bahwa ketika terdapat kenaikan penempatan dana pada PUAS sebesar $1 \%$ maka akan menurunkan pembiayaan perbankan syariah pada sektor PPK sebesar $1.14 \%$. Hal ini sesuai dengan hipotesis awal yang menyatakan variabel PUAS berpengaruh negatif terhadap rasio pembiayaan sektor PPK. Pengaruh negatif variabel PUAS terhadap rasio pembiayaan PPK dikarenakan ketika terjadi peningkatan penempatan dana perbankan pada PUAS maka akan diikuti dengan penurunan porsi penyaluran dana untuk pembiayaan sektor riil, salah satunya untuk pembiayaan sektor PPK.

\subsubsection{Pengaruh Equivalent Rate (ERP) terhadap Rasio Pembiayaan PPK}

Variabel Equivalent Rate pembiayaan (ERP) berpengaruh negatif secara signifikan terhadap pembiayaan sektor PPK pada jangka panjang dengan nilai koefisien sebesar -1.496164. Hal ini berarti setiap kenaikan $1 \%$ pada variabel ERP maka akan menurunkan rasio pembiayaan pada sektor PPK sebesar $1.49 \%$. Keadaan ini disebabkan karena ERP bagi nasabah merupakan bagian dari cost of capital, sehingga ketika ERP meningkat maka akan mengakibatkan meningkatnya biaya produksi dan menyebabkan menurunnya keuntungan yang mereka terima. Hal ini menyebabkan nasabah akan beralih untuk mencari pembiayaan kepada pihak lain yang mampu menawarkan pembiayaan dengan tingkat repayment pembiayaan yang lebih rendah. Oleh karena nasabah sudah tidak tertarik lagi terhadap pembiayaan yang ditawarkan oleh perbankan syariah, maka hal tersebut menyebabkan rasio pembiayaan sektor PPK pada perbankan syariah menurun. 


\subsubsection{Pengaruh SBK terhadap Rasio Pembiayaan PPK}

Variabel Suku Bunga Kredit (SBK) berpengaruh negatif secara signifikan terhadap rasio pembiayaan sektor PPK, dengan nilai koefisien sebesar -2.089452. Hal ini menggambarkan bahwa apabila terjadi kenaikan $1 \%$ pada suku bunga kredit bank konvensional maka akan diikuti dengan menurunnya rasio pembiayaan pada sektor PPK sebesar 2.08\%. Hal ini sesuai dengan hipotesis awal yang menyatakan bahwa variabel SBK berpengaruh negatif terhadap rasio pembiayaan sektor PPK. Keadaan ini dikarenakan ketika SBK meningkat maka akan diikuti oleh prilaku bank konvensional yang akan meningkatkan ekspansi kredit. Besarnya jumlah kredit yang disalurkan oleh bank konvensional akan mengambil sebagian pangsa pasar dari bank syariah, akibatnya hal ini dapat menurunkan rasio pembiayaan perbankan syariah pada sektor PPK.

\subsection{Hasil Analisis Impulse Response Function (IRF)}

Impulse Response Function (IRF) digunakan untuk mengukur respon suatu variabel terhadap suatu guncangan (shock) baik yang diakibatkan oleh variabel itu sendiri maupun variabel lainnya. Serta untuk melihat seberapa lama pengaruh guncangan variabel endogen yang diakibatkan variabel endogen lain dalam satu satuan standar deviasi. Analisis ini menggunakan jangka waktu 60 bulan ke depan. Pada analisis IRF ini akan dijelaskan perbandingan respon rasio pembiayaan sektor PPK jika terdapat guncangan pada variabel DPK, ERP, NPF, INF, IPI, PUAS, SBK, dan BSBIS. Respon rasio pembiayaan sektor PPK jika terjadi guncangan diantaranya:

\subsubsection{Guncangan pada Kategori Kinerja Perbankan}

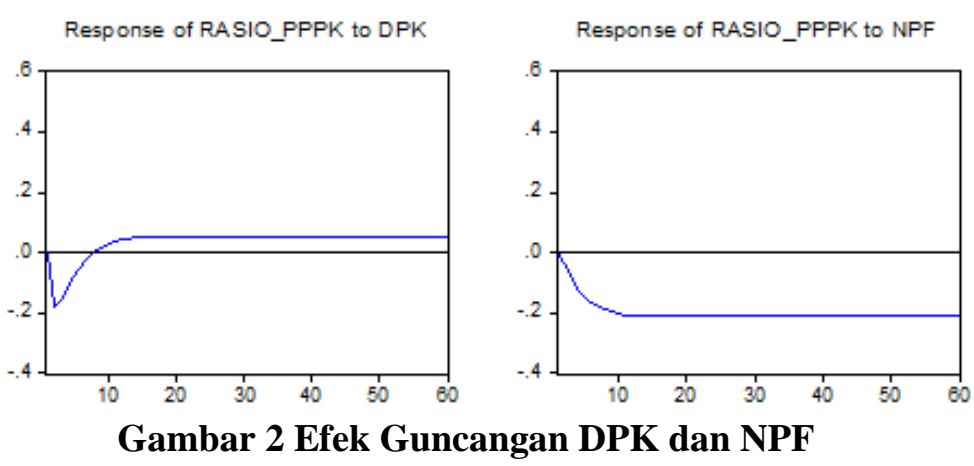

Guncangan variabel DPK sebesar satu standar deviasi tampak belum direspon oleh rasio pembiayaan PPK pada periode pertama. Guncangan ini mulai direspon negatif pada periode kedua sebesar $0.18 \%$. Respon negatif tersebut terus ditunjukkan hingga periode ke-7. Namun pada periode ke-8, tampak respon positif diberikan oleh guncangan variabel DPK terhadap rasio pembiayaan PPK sebesar $0.0009 \%$. Respon positif ini semakin meningkat hingga mencapai kestabilan jangka panjang pada periode ke-25 sebesar $0.05 \%$.

Guncangan variabel Non Performing Financing (NPF) sebesar satu standar deviasi tampak belum direspon oleh rasio pembiayaan PPK pada periode pertama. Guncangan ini mulai direspon negatif oleh rasio pembiayaan PPK pada periode kedua sebesar $0.031 \%$. Respon negatif yang diberikan oleh guncangan NPF semakin meningkat hingga mencapai kestabilan jangka panjang pada periode ke-24 sebesar $0.208 \%$. 


\subsubsection{Guncangan pada Kategori Kondisi Makroekonomi}
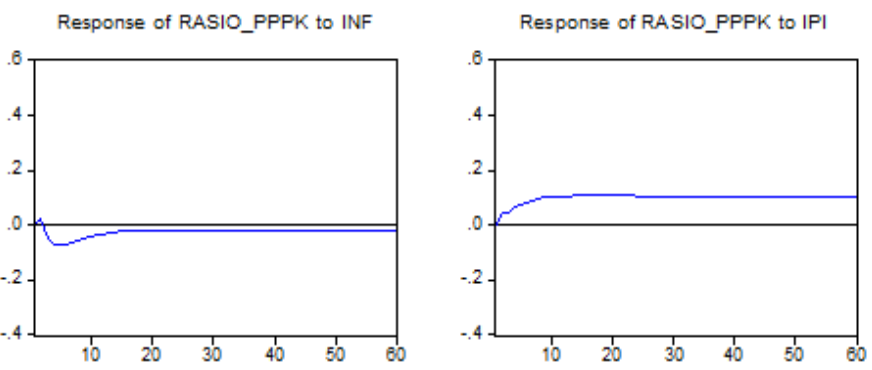

\section{Gambar 3 Efek Guncangan INF dan IPI}

Guncangan variabel inflasi sebesar satu standar deviasi tampak belum direspon oleh rasio pembiayaan PPK pada periode pertama. Guncangan ini mulai direspon positif pada periode kedua sebesar $0.026 \%$. Namun respon positif ini hanya terjadi pada periode kedua di mana pada periode ketiga, guncangan inflasi direspon negatif oleh rasio pembiayaan PPK sebesar $0.045 \%$. Respon negatif ini berangsungangsur menurun hingga mencapai kestabilan jangka panjang yang terjadi pada periode ke-25, di mana rasio pembiayaan PPK merespon negatif guncangan variabel inflasi sebesar $0.017 \%$.

Guncangan variabel IPI sebesar satu standar deviasi pada periode pertama belum direspon oleh rasio pembiayaan PPK. Pada periode kedua, rasio pembiayaan PPK merespon positif guncangan IPI sebesar $0.048 \%$. Respon positif terus meningkat dan mencapai kestabilan jangka panjang pada periode ke-20 sebesar $0.106 \%$.

\subsubsection{Guncangan pada Kategori Instrumen Moneter}
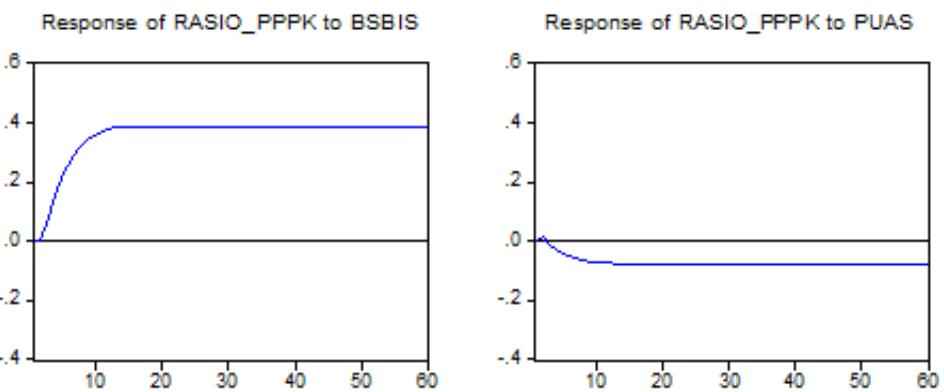

Gambar 4 Efek Guncangan BSBIS dan PUAS

Guncangan bonus SBIS sebesar satu standar deviasi tampak belum direspon oleh rasio pembiayaan PPK pada periode pertama. Pada periode kedua guncangan ini mulai direspon positif oleh rasio pembiayaan PPK sebesar $0.0009 \%$. Respon positif ini semangkin meningkat hingga mencapai kestabilan jangka panjang pada periode ke-26 sebesar $0.387 \%$.

Guncangan variabel PUAS sebesar satu standar deviasi tampak belum direspon oleh rasio pembiayaan PPK pada periode pertama. Guncangan ini mulai direspon positif pada periode kedua sebesar $0.019 \%$, namun respon positif ini hanya terjadi pada periode kedua. Pada periode ketiga, guncangan variabel PUAS direspon negatif oleh rasio pembiayaan PPK sebesar 0.013\%. Respon negatif ini semangkin meningkat hingga mencapai kestabilan jangka panjang pada periode ke-26 sebesar $0.074 \%$. 


\subsubsection{Guncangan pada Kategori Rate of Return}
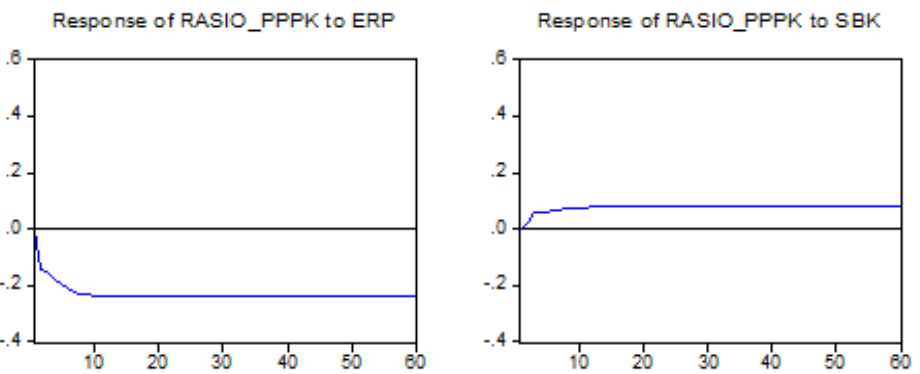

Gambar 5 Efek Guncangan ERP dan SBK

Guncangan equivalent rate pembiayaan (ERP) sebesar satu standar deviasi tampak belum direspon oleh rasio pembiayaan PPK pada periode pertama. Guncangan ini mulai direspon negatif oleh rasio pembiayaan PPK pada periode kedua sebesar $0.145 \%$. Respon negatif rasio pembiayaan PPK semakin meingkat hingga mencapai kestabilan jangka panjang pada periode ke-22, di mana rasio permbiayaan PPK merespon negatif guncangan tersebut sebesar $0.236 \%$.

Guncangan suku bunga kredit (SBK) sebesar satu standar deviasi tampak belum direspon oleh rasio pembiayaan PPK pada periode pertama. Guncangan ini mulai direspon positif oleh rasio pembiayaan PPK pada periode kedua sebesar $0.022 \%$. Respon positif ini semangkin meningkat hingga mencapai kestabilan jangka panjang pada periode ke-25, di mana rasio permbiayaan PPK merespon positif guncangan tersebut sebesar $0.080 \%$.

\subsection{Hasil Forecasting Error Variance Decomposition (FEVD)}

Analisis Forecasting Error Variance Decomposition (FEVD) digunakan untuk mengidentifikasi variabel yang memberi kontribusi paling besar dalam menjelaskan keragaman rasio pembiayaan sektor PPK pada perbankan syariah. Hasil dari FEVD terhadap rasio pembiayaan PPK menunjukkan fluktuasi pembiayaan PPK ditentukan oleh shock dari semua variabel dalam penelitian (Gambar 6).

Hasil menunjukkan bahwa pada periode pertama pembiayaan masih $100 \%$ dipengaruhi oleh pembiayaan itu sendiri. Kemudian pada periode berikutnya tampak variabilitas rasio pembiayaan PPK mulai dijelaskan oleh variabel-variabel lainnya. Periode kedua menunjukkan pembiayaan masih dominan dipengaruhi oleh pembiayaan itu sendiri sebesar 91.29\%, DPK 4.84\%, NPF 0.14\%, ERP $3.13 \%$, SBK $0.072 \%$, BSBIS $0.00012 \%$, INF $0.101 \%$, IPI 0.35\%, dan PUAS $0.05 \%$.

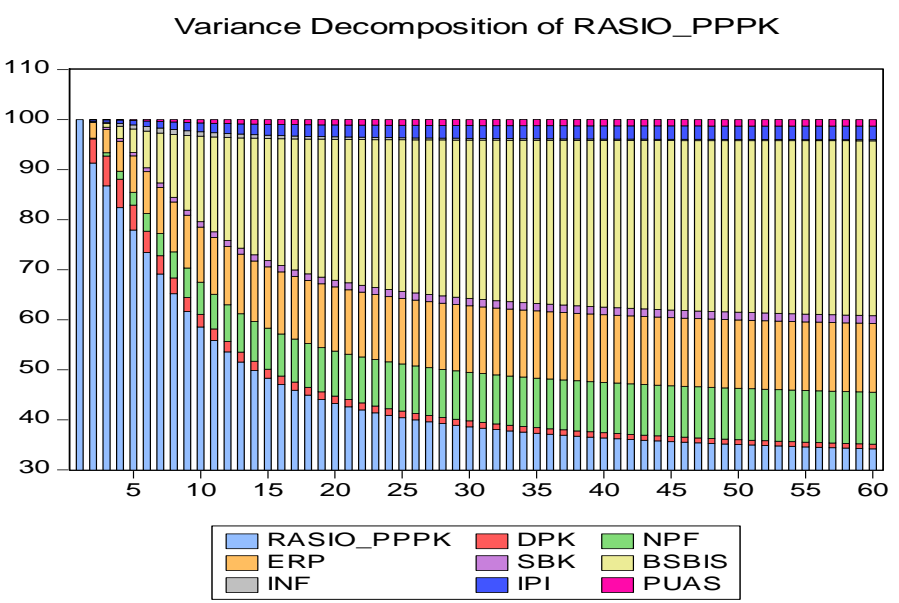

Gambar 11 Forecasting Error Variance Decomposition (FEVD) 
Periode-periode berikutnya menunjukkan penurunan pengaruh rasio pembiayaan PPK terhadap variabilitas itu sendiri dan terdapat peningkatan pengaruh dari variabel lainnya. Hingga akhirnya di periode ke-60 kontribusi masing-masing variabel terhadap keragaman rasio pembiayaan PPK secara berurut dari yang terbesar hingga terkecil yaitu variabel BSBIS sebesar 34.93\%, rasio pembiayaan PPK $34.19 \%$, ERP $13.75 \%$, NPF 10.39, IPI 2.72\%, SBK $1.55 \%$, PUAS $1.31 \%$, DPK $0.91 \%$, dan terkecil yaitu INF sebesar $0.20 \%$. Secara keseluruhan, untuk analisis Forecasting Error Variance Decomposition (FEVD) menunjukkan bahwa selain pembiayaan PPK itu sendiri, variabel yang membentuk keragaman pada pembiayaan PPK dengan kontribusi paling besar dijelaskan oleh variabel bonus Sertifikat Berharga Indonesia Syariah (SBIS), Equivalent Rate (ERP), dan Non Performing Financing (NPF).

\section{Kesimpulan dan Saran}

\subsection{Kesimpulan}

Berdasarkan penelitian yang telah dilakukan maka diperoleh kesimpulan sebagai berikut:

1. Pada jangka pendek hanya variabel DPK yang secara signifikan berpengaruh negatif, sedangkan pada jangka panjang secara signifikan variabel NPF, INF, ERP, PUAS, dan SBK memberikan pengaruh negatif terhadap rasio pembiayaan sektor PPK dan variabel IPI serta BSBIS secara signifikan memberikan pengaruh positif pada rasio pembiayaan sektor PKK.

2. Ketika variabel NPF, PUAS, ERP, dan INF mengalami guncangan sebesar satu standar deviasi maka akan direspon negatif oleh rasio pembiayaan sektor PPK perbankan syariah, sedangkan apabila terdapat guncangan pada variabel DPK SBK, IPI, dan BSBIS sebesar satu standar deviasi maka akan direspon secara positif oleh rasio pembiayaan sektor PPK.

3. Variabel yang membentuk keragaman pada pembiayaan sektor PPK dengan kontribusi terbesar dijelaskan oleh variabel bonus Sertifikat Bank Indonesia Syariah (BSBIS), lalu diikuti oleh variabel equivalent rate pembiayaan (ERP), Non Performing Financing (NPF), dan Industrial Production Index (IPI).

\subsection{Saran}

Berdasarkan penelitian yang telah dilakukan, terdapat beberapan saran yang dapat peneliti berikan, diantaranya:

1. Perbankan syariah sebagai lembaga intermediasi hendaknya meningkatkan penyalurkan pembiayaan pada sektor PPK dengan proporsi yang lebih tinggi dibanding dengan menempatkan dana pada Pasar Uang Antar Bank Syariah (PUAS). Berkurangnya proporsi penyaluran dana pada PUAS diharapkan menjadikan perbankan syariah dapat lebih fokus menyalurkan dana yang dimiliki pada sektor riil khususnya sektor PPK.

2. Kondisi Non Performing Financing (NPF) yang begitu tinggi, secara signifikan dapat berpengaruh negatif terhadap rasio pembiayaan sektor PPK, untuk mengurangi kemungkinan terjadinya pembiayaan bermasalah, perbankan syariah sebaiknya meningkatkan sistem monitoring yang dimilikinya, sehingga dengan meningkatnya kualitas dari sistem tersebut diharapkan jumlah pembiayaan bermasalah dapat ditekan seminimal mungkin.

3. Keragaman rasio pembiayaan sektor PPK yang didominasi oleh faktor bonus SBIS dan tingkat rate of return menunjukkan bahwa perlu adanya perhatian khusus dari otoritas moneter yaitu Bank Indonesia terhadap tingkat BI Rate. Bank Indonesia diharapkan dapat mengontrol tingkat BI Rate secara tepat, dikarenakan tingkat BI Rate dapat mempengaruhi besaran dari bonus SBIS serta tingkat rate of return sehingga dengan tingkat BI Rate yang tepat diharapkan penyaluran pembiayaan pada sektor PPK dapat lebih baik.

4. Penelitian selanjutnya dapat dilakukan dengan menambahkan variabel untuk setiap kategori faktor dan menambah periode pengamatan, selain itu dapat pula dilakukan perbandingan antara perbankan syariah dan perbankan konvensional. 


\section{Daftar Pustaka}

Antonio, M.S. 2001. Bank Syariah: Dari Teori ke Praktik. Jakarta(ID): Gema Insani Press.

Ascarya. 2010a. Alur Transmisi dan Efektifitas Kebijakan Moneter Ganda di Indonesia. Jakarta (ID): PPSK Working Paper Series No: WP/10/03. Bank Indonesia.

Ascarya. 2012. Alur transmisi dan efektivitas kebijakan moneter ganda di Indonesia. Jakarta (ID): Buletin Ekonomi Moneter dan Perbankan Edisi Januari 2012.

[BI] Bank Indonesia. 2008-2014. Statistik Ekonomi dan Keuangan Indonesia (SEKI) [internet]. [diunduh 2015 Februari 04]. Tersedia pada: http://www.bi.go.id

[BI] Bank Indonesia. 2008-2014. Statistik Perbankan Indonesia. Direktorat Perbankan Indonesia [internet]. [diunduh 2015 Januari 24]. Tersedia pada: http://www.bi.go.id

[BI] Bank Indonesia. 2008-2014. Statistik Perbankan Syariah. Direktorat Perbankan Syariah [internet]. [diunduh 2015 Januari 23]. Tersedia pada: http://www.bi.go.id

[BPS] Badan Pusat Statistik. 2015. Berita Resmi Statistik [Internet]. [diunduh 2015 Februari 23]. Tersedia pada: http://www.bps.go.id

[BPS] Badan Pusat Statistik. 2009. Klasifikasi Baku Lapangan Usaha Indonesia (KBLI) [Internet]. [diunduh 2015 Februari 23]. Tersedia pada: http://www.bps.go.id

Engle, R.F. 1982. Autoregressive Conditional Heteroscedasticity with Estimates of the Variance of United Kingdom Inflation. Econometrica.

Firdaus, M. 2011. Aplikasi Ekonometrika untuk Data Panel dan Time Series. Jakarta (ID): IPB Press.

Gujarati, D.N. 2006. Dasar-Dasar Ekonometrika. Jilid 1. Julius A Mulyadi, penerjemah. Jakarta (ID): Erlangga

Kasmir. 2002. Dasar-Dasar Perbankan. Jakarta (ID): PT. Raja Grafindo Persada.

Kementerian Kelautan dan Perikanan. 2012. Kebijakan Ekonomi Kelautan dengan Model Ekonomi Biru. Jakarta.

Kementerian Perencanaan Pembangunan Nasional. 2014. Rancangan Anggaran Pendapatan dan Belanja Negara (RAPBN) [Internet]. [diunduh 2015 Mei 06]. Tersedia pada: http://www.bappenas.go.id

Kementerian Perencanaan Pembangunan Nasional. 2014. Rancangan Teknokrat Rencana Pembangunan Jangka Menengah Nasinoal (RPJMN) [Internet]. [diunduh 2015 Mei 06]. Tersedia pada: http://www.bappenas.go.id

Peek et al. (2000). Identifying the macroeconomic effect of loan supply shocks. Boston : htttp;/www.papers.ssrn.com.

Reed, E.W. 1989. Commercial Banking. New Jersey (US):Prentice-Hall

Nugroho, R. 2009. Analisis Faktor-Faktor Penentu Pembiayaan Perbankan Syariah di Indonesia: Aplikasi Model Vector Error Correction. [tesis]. Bogor (ID): Fakultas Ekonomi dan Manajemen, Institut Pertanian Bogor.

Warjiyo, P. 2004. Mekanisme Transmisi Kebijakan Moneter Indonesia. Jakarta (ID): Pusat Pendidikan dan Studi Kebanksentralan. 
